Article

\title{
Expression Profile of PIN-Formed Auxin Efflux Carrier Genes during IBA-Induced In Vitro Adventitious Rooting in Olea europaea L.
}

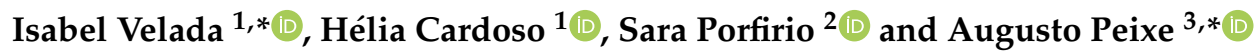 \\ 1 MED—Mediterranean Institute for Agriculture, Environment and Development, Instituto de Investigação e \\ Formação Avançada, Universidade de Évora, Pólo da Mitra, Ap. 94, 7006-554 Évora, Portugal; \\ hcardoso@uevora.pt \\ 2 Complex Carbohydrate Research Center, The University of Georgia, 315 Riverbend Road, Athens, GA 30602, \\ USA; porfirio@uga.edu \\ 3 MED-Mediterranean Institute for Agriculture, Environment and Development \& Departamento de \\ Fitotecnia, Escola de Ciências e Tecnologia, Universidade de Évora, Pólo da Mitra, Ap. 94, \\ 7006-554 Évora, Portugal \\ * Correspondence: ivelada@uevora.pt (I.V.); apeixe@uevora.pt (A.P.)
}

Received: 17 January 2020; Accepted: 2 February 2020; Published: 3 February 2020

\begin{abstract}
Exogenous auxins supplementation plays a central role in the formation of adventitious roots (AR) for several plant species. However, the molecular mechanisms underlying the process of adventitious rooting are still not completely understood and many plants with economic value, including several olive cultivars, exhibit a recalcitrant behavior towards cutting propagation, which limits its availability in plant nurseries. PIN-formed proteins are auxin efflux transporters that have been widely characterized in several plant species due to their involvement in many developmental processes including root formation. The present study profiled the expression of the OePIN1a-c, OePIN2b, OePIN3a-c, OePIN5a-c, OePIN6, and OePIN8 gene members during indole-3-butyric acid (IBA)-induced in vitro adventitious rooting using the olive cultivar 'Galega vulgar'. Gene expression analysis by quantitative real time PCR (RT-qPCR) showed drastic downregulation of most transcripts, just a few hours after explant inoculation, in both nontreated and IBA-treated microcuttings, albeit gene downregulation was less pronounced in IBA-treated stems. In contrast, OePIN2b showed a distinct expression pattern being upregulated in both conditions, and OePIN5b was highly upregulated in IBA-induced stems. All transcripts, except OePIN8, showed different expression profiles between nontreated and IBA-treated explants throughout the rooting experiment. Additionally, high levels of reactive oxygen species (ROS) were observed soon after explant preparation, decreasing a few hours after inoculation. Altogether, the results suggest that wounding-related ROS production, associated with explant preparation for rooting, may have an impact on auxin transport and distribution via changes in OePIN gene expression. Moreover, the application of exogenous auxin may modulate auxin homeostasis through regulation of those genes, leading to auxin redistribution throughout the stem-base tissue, which may ultimately play an important role in AR formation.
\end{abstract}

Keywords: olive; auxin; plant propagation; PIN; adventitious roots; reactive oxygen species (ROS); wounding; gene expression

\section{Introduction}

Auxins are an important group of phytohormones that influence cell division, cell elongation, and cell differentiation and thus have been widely reported to be involved in the control of plant growth and development [1-3]. Several studies have been performed on the involvement of auxins, 
for example, in the regulation of zygotic embryo development, [4], general shoot and root development and architecture [5-9], tropisms [10-12], temporal coordination of plant tolerance to stress [13-15], apical dominancy regulation [16,17], development of leaves and flowers [18,19], nodulation [20], or organ initiation at the shoot apex [21-23].

Although auxins were long believed to be mainly synthesized in the young leaves and apical meristem of the shoot [24], more recent studies found that both shoots and roots can produce auxins [25]. From the primary biosynthesis sites, auxins are distributed throughout the plant by two interconnected transport systems, one consisting of a fast nondirectional stream in the phloem along with photosynthetic assimilates, and the other comprising the polar auxin transport (PAT) system [1]. PAT is the major auxin distribution pathway, dispersing auxin from cell-to-cell in a slow and direct manner, and thus is determinant for the spatio-temporal dissemination of that molecule within tissues during plant development. This is achieved by establishing defined auxin gradients (auxin homeostasis), involving local auxin maxima or local auxin optima, which inhibit and promote, respectively, cell division, expansion, or differentiation [1,26-29]. There are three main classes of auxin membrane transporters mediating the PAT system: the influx carriers auxin permease 1 (AUX1)/LAX, and two classes of efflux carriers, namely (1) the ATP-BINDING cassette subfamily B (ABCB; previously known as multidrug resistance (MDR)/Phosphoglycoprotein (PGP)) transporters, and (2) the PIN-formed (PIN) proteins [27].

In Arabidopsis, the PIN family consists of eight members grouped into two subclasses according to the length of their central hydrophilic loop. Canonical 'long' or 'PIN1-type' proteins (PIN1, PIN2, PIN3, PIN4, and PIN7) localize to the plasma membrane (PM). Nevertheless, they do not reside statically in the PM but constitutively cycle between the PM and endosomal compartments. The three remaining members of the AtPIN family display a partly (PIN6) or dramatically reduced (PIN5 and PIN8) central hydrophilic loop (reviewed by [30]). The PIN efflux carriers are being widely characterized in several plant species and various functions have been attributed to PIN proteins in plants. Among these are functions related to root initiation and development, as is the case of PIN1 [31], PIN3, PIN5, and PIN6 (reviewed by [32]).

The formation of adventitious roots (AR) is a developmental process where new roots arise from stems, leaves, or non-pericycle tissues in old roots. AR may be formed naturally or under stressful environmental situations, and they may be also induced by mechanical injury or following tissue culture regeneration of shoots [33-35]. The process of AR formation has been studied in olive (Olea europaea subsp. europaea var. europaea L.) (reviewed by [36]) because this crop comprises several cultivars with reduced capacity to be propagated given its recalcitrance towards adventitious rooting. The cultivar 'Galega vulgar' is one of those cultivars, displaying a difficult-to-root behavior. Microcuttings of this cultivar treated with IBA (indole 3-butyric acid) have been used to study the molecular mechanisms underlying the formation of AR. The olive adventitious rooting process is considered a developmental process organized in a sequence of interdependent stages, including (1) an induction phase corresponding to the first 4 days after microcutting treatment and inoculation; (2) an initiation phase, from 4 to 14 days after treatment, when the first meristemoids and morphogenetic root zones are observed; and (3) the expression phase, which starts at 22 days after the root-inducing treatment [37].

Auxins play a central role in the control of adventitious rooting [38-41], and for that reason are widely used as an inducer of the process. Indeed, auxin transport, particularly through PIN auxin carriers, is a key factor in AR formation $[31,42,43]$. AR in olive cuttings has been suggested as a direct growth response, involving a stress-induced reprogramming of shoot cell fate by which plants diminish stress exposure [44-46]. Another group of signaling molecules described as central players in the coordination of responses to biotic and abiotic stresses in plants, as well as in the regulation of plant growth and development, are reactive oxygen species (ROS) [47]. The existence of cross-talk between ROS and auxin homeostasis and signaling has been largely reported [48-56], under the assumption 
that, for example, ROS can alter directional transport of auxin by inducing auxin-conjugating enzymes, or reducing the transcription of auxin-responsive genes.

Despite the great attention that has been given to the PIN-formed auxin efflux transporter genes in many plant species, both in model and crop plants (reviewed by [32]) and in many aspects of plant development and growth, including in AR formation, to the best of our knowledge, there is a lack of information on this subject in olive. Therefore, this work aimed to analyze the expression pattern of several members of the PIN gene family in olive stem-base tissues during IBA-induced rooting of in vitro-cultured microshoots of cv. 'Galega vulgar', in order to contribute to a growing body of knowledge on the molecular mechanisms underlying this developmental process.

\section{Results}

\subsection{Gene Expression Analysis}

The expression of the putative OePIN1a-c, OePIN2b, OePIN3a-c, OePIN5a-c, OePIN6, and OePIN8 transcripts was analyzed in both IBA-treated and nontreated microcuttings up to 17 days after inoculation.

A downregulation in the expression of most of the transcripts was observed $4 \mathrm{~h}$ soon after inoculation in both nontreated (OePIN1a: 141-fold change, $p \leq 0.001$; OePIN1b: 9-fold change, $p \leq 0.05$; OePIN1c: 6.4-fold change, $p \leq 0.001$; OePIN3a: 14-fold change, $p \leq 0.001$; OePIN3b: 43-fold change, $p \leq$ 0.05; OePIN3c: 12.5-fold change, $p \leq 0.05$; OePIN5a: 6-fold change, $p \leq 0.05$; OePIN5c: 72-fold change, $p \leq 0.001$; OePIN6: 5.8-fold change, $p \leq 0.001$ ) and IBA-treated (OePIN1a: 55-fold change, $p \leq 0.05$; OePIN1b: 6.6-fold change, $p \leq 0.001$; OePIN1c: 2.8 -fold change, $p \leq 0.001$; OePIN3a: 4.3-fold change, $p \leq 0.05$; OePIN3b: 16.9-fold change, $p \leq 0.05$; OePIN3c: 17.5-fold change, $p \leq 0.001$; OePIN5a: 1.7-fold change, $p \leq 0.001$; OePIN5c: 20-fold change, $p \leq 0.05$ : OePIN6: 6-fold change, $p \leq 0.05$ ) microcuttings (Figure 1). With the exception of OePIN3c and OePIN6, gene downregulation was less pronounced upon IBA treatment. Transcript downregulation was particularly drastic for OePIN1a, OePIN3b, and OePIN5c, within each of the corresponding gene subfamilies, with reductions over 40-fold changes in nontreated samples.

OePIN1a-c expression levels show significant differences between nontreated and IBA-treated microcuttings. Interestingly, and although the expression profile is similar between conditions, in IBA-treated samples, the expression of all three transcripts is higher than in nontreated samples from $4 \mathrm{~h}$ up to day 1 (i.e., during the induction phase). From day 4 until the end of the trial (i.e., during the initiation phase) this pattern was reversed and, overall, the expression of all three transcripts is lower in IBA-treated samples than in nontreated ones.

In contrast to most other genes analyzed here, OePIN $2 b$ exhibited a unique expression profile, being upregulated $4 \mathrm{~h}$ after inoculation with similar increments in both conditions, 3-fold change $(p \leq 0.05)$ in nontreated explants, and 2.6-fold change $(p \leq 0.001)$ in IBA-treated explants. From $8 \mathrm{~h}$ onwards, mRNA levels tended to decrease, reaching the basal expression levels in both conditions at the end of the rooting experiment.

Within the OePIN5 gene subfamily, distinct expression profiles were observed for all three transcripts and between conditions within each transcript. OePIN5b showed the most interesting results, with the most relevant differences between the two conditions. While in nontreated samples OePIN5b mRNA levels remained stable throughout the rooting trial, in IBA-treated samples the expression of this gene was highly upregulated (35-fold change, $p \leq 0.001$ ) up to $8 \mathrm{~h}$ after inoculation, maintained up to day 1 and downregulated until the end of the rooting experiment when it reached the basal levels. On the other hand, the expression of OePIN5a in nontreated microcuttings raised from $4 \mathrm{~h}$ onwards, exceeding the basal expression levels, while in IBA-treated microcuttings an expression peak was observed around day 1 , followed by a downregulation up to 17 days post inoculation, until basal levels were reached. Interestingly, both OePIN5a and OePIN5b had an expression peak around day 1 in IBA-treated samples but in nontreated samples the expression was similar to basal levels. 
Meanwhile, at 17 days after inoculation, OePIN5b reached basal expression levels in both conditions, while OePIN5a only reached these levels in the IBA-treated samples. On the contrary, OePIN5c mRNA remained below basal levels throughout the rooting experiment in both conditions. In contrast to nontreated samples, in IBA-treated samples this transcript decreased more sharply until the end of the trial, reaching levels tremendously low at 17 days post inoculation.
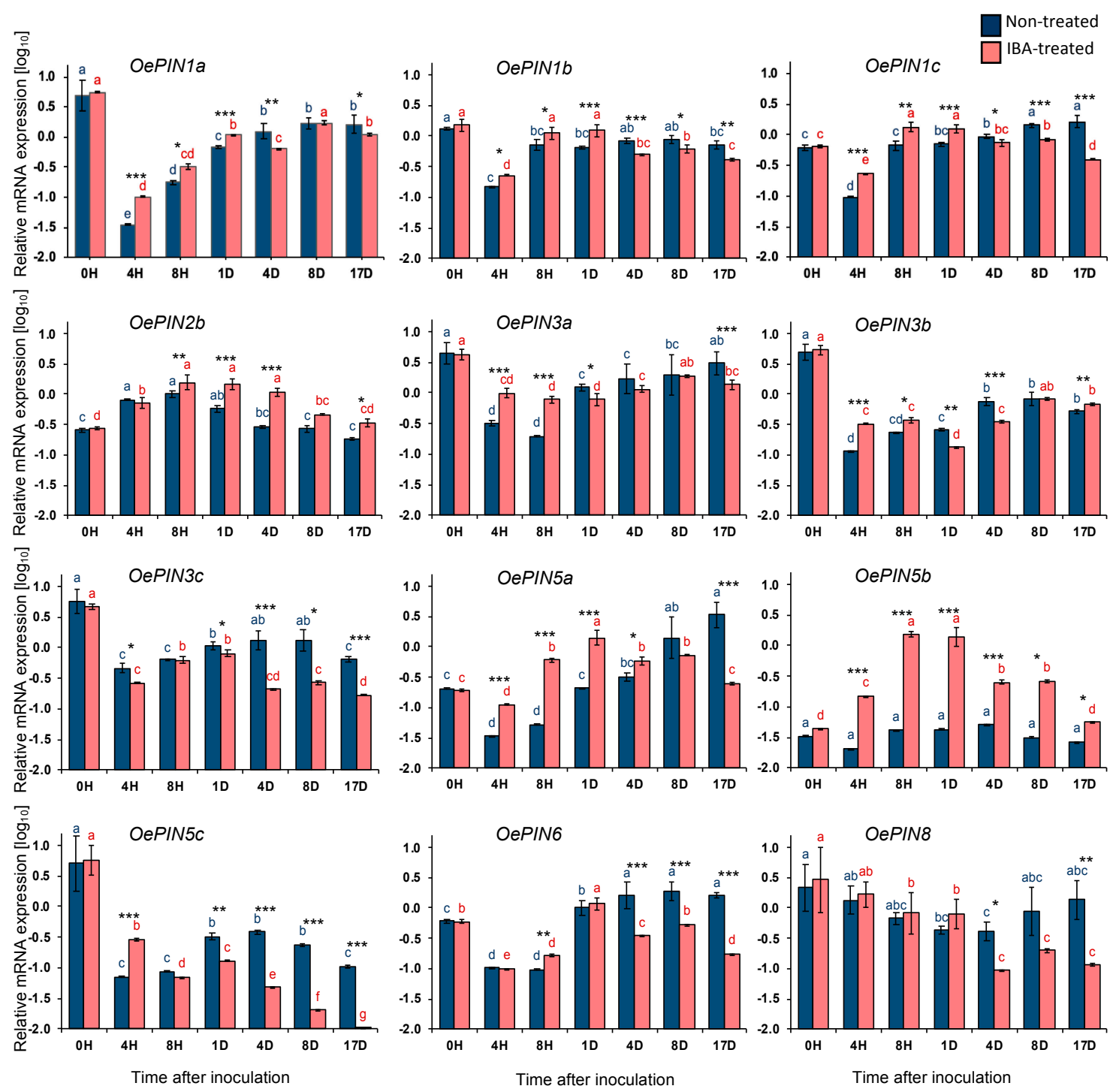

Figure 1. Relative mRNA expression of OePIN genes in stem basal segments of Olea europaea L. microcuttings during indole-3-butyric acid (IBA)-induced adventitious rooting. The relative expression values are depicted as the mean (Log10 transformed) \pm the standard error of the mean (SEM) of four biological replicates (each consisting of 20 stem basal segments) for each time point. Distinct letters $(p<0.05)$ and asterisks $\left({ }^{*} p \leq 0.05,{ }^{* *} p \leq 0.01,{ }^{* * *} p \leq 0.001\right)$ indicate statistically significant differences. H: hours; D: days.

Regarding OePIN6, from $4 \mathrm{~h}$ up to day 1, mRNA levels were upregulated in both conditions. From day 1 onwards, the tendency was for OePIN6 mRNA levels to decrease in IBA-treated samples, but to remain stable and above basal levels in nontreated samples until the end of the rooting induction experiment. This expression pattern was similar to that observed for OePIN5a.

Finally, and despite the high variability observed among samples in both conditions, there was a similar tendency for reduction of OePIN8 transcript amounts in both conditions up to day 1 . 
Subsequently, transcript amounts kept decreasing in IBA-treated samples, while in nontreated samples they recovered basal values until the end of the experiment.

\subsection{ROS Accumulation in Stem-Base Tissues}

We evaluated the accumulation $\mathrm{H}_{2} \mathrm{O}_{2}$ and $\mathrm{O}_{2}{ }^{--}$in olive stem-base tissues using 3,3'-diaminobenzidine (DAB) and nitroblue tetrazolium (NBT) stainings, respectively, in nontreated and IBA-treated microcuttings (Figure 2). We found that soon after explant preparation for rooting (at $0 \mathrm{~h}$, prior to inoculation) high staining intensity for both DAB (Figure 2A,C) and NBT (Figure 2E,G) substrates was observed in both types of stem, indicating high accumulation of ROS. Eight hours after inoculation, tissue discoloration was observed for both DAB (Figure 2B,D) and NBT (Figure 2F,H) chromogenic substrates, in both conditions, revealing that ROS levels decreased in nontreated and IBA-treated explants a few hours after inoculation

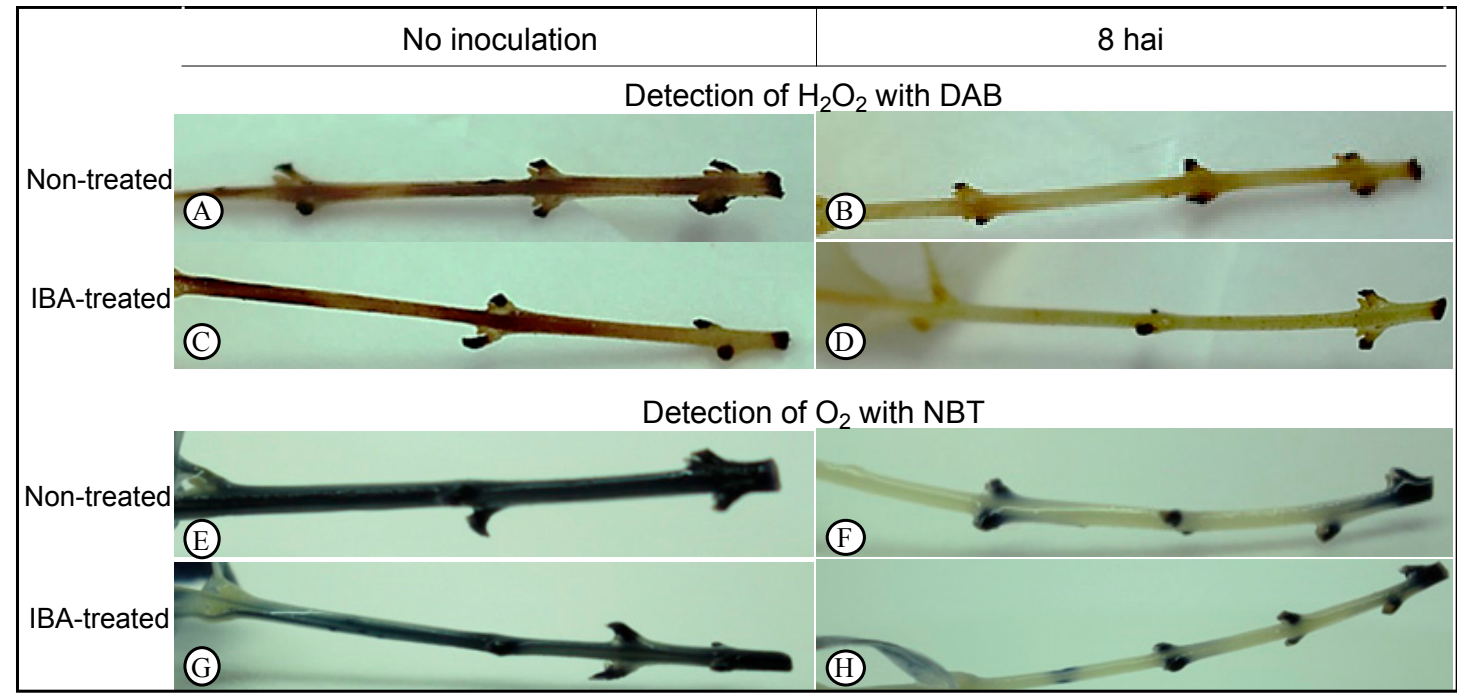

Figure 2. Detection of hydrogen peroxide $\left(\mathrm{H}_{2} \mathrm{O}_{2}\right)$ with $3,3^{\prime}$-diaminobenzidine (DAB) (A-D) and superoxide anion $\left(\mathrm{O}_{2}\right)$ with nitroblue tetrazolium (NBT) $(\mathbf{E}-\mathbf{H})$. Histochemical detection analyses were performed at $0 \mathrm{~h}$ after inoculation (hai) (no inoculation) and at $8 \mathrm{hai}$ in the culture medium.

\section{Discussion}

Auxins play a central role in the control of adventitious rooting [38]. Trying to understand whether auxin transport could be impaired in difficult-to-root olive cultivars, we analyzed the expression of the olive PIN-formed gene family during IBA-induced in vitro adventitious root formation using the cultivar 'Galega vulgar'.

To the best of our knowledge, this study shows for the first time the expression profile of the putative OePIN1a-c, OePIN2b, OePIN3a-c, OePIN5a-c, OePIN6, and OePIN8 transcripts in olive stem-base tissues.

When looking at gene expression results in nontreated explants alone, our results indicate that most OePIN gene members were negatively affected by the explant preparation procedure, since gene expression was downregulated just a few hours after explant preparation and inoculation (Figure 1). This was observed for all transcripts analyzed, except for OePIN $2 b$. This drastic downregulation might be related to the plant's response to the stress situation (i.e., wounding) associated with explant preparation. In fact, the occurrence of high levels of ROS was demonstrated soon after explant preparation (prior to inoculation, at 0 hai) (Figure 2A,C,E,G), which are indicative of the presence of oxidative stress [57]. ROS are key signaling molecules that regulate growth and development and coordinate responses to biotic and abiotic stresses in plants [47]. The existence of cross-talk between ROS and auxin signaling has been reported [48], where stress-induced ROS production can alter auxin homeostasis [49,50] and also 
inhibit auxin-mediated signaling [55,58], while activating oxidative stress signaling [52]. ROS directly influence the action of auxins by a $\mathrm{H}_{2} \mathrm{O}_{2}$-dependent mitogen-activated protein kinase (MAPK) cascade that negatively affects auxin sensitivity by downregulating auxin-inducible gene expression [54]. On the other hand, auxins can induce the production of ROS [48] and regulate ROS homeostasis [51]. Therefore, ROS and auxins have been reported as regulators of plant development during stress [48-50]. ROS affect auxin signaling in different ways. Increased ROS levels may affect auxin signaling and homeostasis by affecting auxin biosynthesis, conjugation, degradation, and distribution [48,51,59]. Specifically, ROS can alter the directional transport of auxin through changes in the expression of genes encoding auxin transporters [60]. Indeed, it has been reported that ROS production under environmental stress can have an impact on auxin redistribution via repression of the polar auxin transporters [48]. An example is the data obtained by Blomster et al. [53] who demonstrated that apoplastic ROS negatively affect the expression of several transcripts encoding auxin efflux carriers. In line with these results, Pasternak and co-authors [51] showed that the expression of PIN1 and PIN3 genes decreases under oxidative stress-related growth conditions induced by alloxan. Another example involves sorghum (Sorghum bicolor), where the transcriptional analysis of auxin transporter genes revealed that their expression levels are affected by abiotic stresses, such as salt and drought [61], whereas cold stress impacts the intracellular trafficking of a subset of proteins, including PIN2 and PIN3, that inhibit auxin transport in the roots [62]. In our study, the correlation found between high ROS accumulation and downregulated OePIN genes corroborates those earlier studies reporting an impact of ROS on auxin transport. The crosstalk between ROS and auxins is on the basis of the so-called stress-induced morphogenic responses where stressed plants develop a general acclimation strategy, whereby plant growth is not ceased but instead redirected to diminish stress exposure. In fact, several events in developmental and growth processes are mediated by auxin signaling and the suppression of auxin signaling by mitochondrial ROS positions mitochondria as an important hub in the cellular signaling cascade that can block auxin signaling and thus play a central role in determining if cellular resources are used for growth (signaled by auxin) or stress resistance (signaled by ROS) [48-50]. With regard to AR formation, Santos Macedo and collaborators [63] have suggested that in olive this process is considered a stress-induced morphogenic response which involves reprogramming of the shoot cells $[44,45,63]$.

When IBA was applied to the base of the olive stems, gene downregulation was less pronounced compared to nontreated stems, suggesting that auxin-sensitive cells are probably being induced to express PIN genes in response to the application of exogenous auxin. Nevertheless, this induction is not enough to overcome the stress impact on PIN gene downregulation observed in nontreated stems. Indeed, there are several studies reporting induced expression of PIN genes following exogenous auxin application. For instance, IBA induces PIN1 during adventitious rooting in Arabidopsis thaliana thin cell layers [64]. Similarly, the genes CpPIN1, CpPIN2, CpPIN3, and CpPIN4 increased their expression in response to IBA in Carica papaya [65]. In turn, maize genes ZmPIN1a and ZmPIN1c showed significantly upregulated expression after IAA treatment [66]. Likewise, OsPIN1 $a$ and OsPIN1b were induced by IAA in rice [67].

PIN1, PIN2, and PIN3 are located to the plasma membrane and play important roles in polar auxin transport [68]. In our study, we observed significant differences in OePIN1a-c expression levels between nontreated and IBA-treated microcuttings. While from $4 \mathrm{~h}$ up to day 1 (during the induction phase) the expression of all three transcripts is higher in IBA-treated samples, from day 4 until the end of the trial (during the initiation phase) the expression of all three transcripts is lower in IBA-treated samples, suggesting a reduction in auxin transport which probably has an effect on auxin redistribution throughout the stem-base tissues. This expression pattern was also observed for OePIN3 (other PIN gene also playing important roles in PAT). Indeed, in nontreated microcuttings the expression profile of OePIN3b and OePIN3c was very similar throughout the rooting trial. However, in IBA-treated microcuttings the expression of OePIN $3 b$ and OePIN3c transcripts was quite different, particularly during the initiation phase (from 4 up to 14 days), suggesting that the application of exogenous auxins 
might be promoting a differential regulation of the direction in which PAT occurs. PIN1 has been associated with adventitious root development. For example, OsPIN1 is involved in adventitious root emergence in rice [31] and AtPIN1 is expressed during adventitious rooting in the hypocotyl of Arabidopsis seedlings and it induces auxin levels for AR initiation [69]. Additionally, Sukumar et al. [70] found that PIN1 and PIN3 mutations reduce AR formation in the hypocotyls of Arabidopsis seedlings.

$O e P I N 2 b$ showed an expression profile distinct from all other studied transcripts, being upregulated in both conditions instead of downregulated. It should be noted that this gene is the only one upregulated in nontreated stems, suggesting that it might be induced by wounding-related stress. In fact, PIN proteins are also involved in plant responses to stress situations [66,71,72], and PIN2 has even been referred to as a general stress target underlying the adaptive response of roots to abiotic stress [73]. Additionally, OsPIN2 was found to be induced by cold stress and drought [74].

PIN5, a short PIN protein displaying a dramatically reduced central hydrophilic loop, is localized to endoplasmic reticulum (ER) where it mediates auxin flow from the cytoplasm into the ER lumen. AtPIN5 is pointed out to have a function in the regulation of intracellular auxin homeostasis and metabolism through subcellular compartmentalization $[29,68,75]$. Expression patterns differed considerably among the three OePIN5 transcripts in nontreated explants, but when exogenous auxin was applied the expression profiles became very similar, particularly those of OePIN5a and OePIN5b, with a maximum expression around day 1 , suggesting that the application of exogenous auxin may be regulating OePIN5a and OePIN5b transcripts in the same manner. The most interesting result involved OePIN5b whose expression increased considerably $8 \mathrm{~h}$ after inoculation in IBA-treated samples, suggesting the gene is likely being induced by exogenous auxin. Lu and collaborators [76], using rice transgenic lines with elevated and reduced OsPIN5b, also observed that OsPIN5b was induced by treatment with synthetic auxin. The same authors observed that transgenic lines overexpressing OsPIN5b presented high free IAA levels and less auxin conjugates, suggesting that OsPIN5b modulates auxin homeostasis leading to changes in auxin transport and distribution. In line with the results from Lu and collaborators [76], we also observed that upon IBA treatment the maximum expression peak for OePIN5b correlates with the maximum peak in free auxin levels observed by Porfirio et al. [34] using the same experimental system. In contrast, Mravec et al. [75] suggested that AtPIN5, by transporting auxin intracellularly from the cytoplasm into the ER lumen, reduces auxin availability for plasma-membrane-based auxin efflux, since they observed that PIN5 gain-of-function at the ER leads to lower free IAA levels. It is tempting to speculate that the application of exogenous auxin might regulate OePIN5 transcripts, therefore affecting auxin homeostasis. This could lead to changes in auxin distribution and transport in the stem-base tissues, which may in turn play a role in the initiation of AR in olive microshoots. Additionally, the altered expression profile of OePIN1 and OePIN3 (both involved in PAT) in IBA-treated microshoots could also contribute to changes in auxin transport and distribution.

AtPIN5, AtPIN6, and AtPIN8 share the following features: a reduction of the central hydrophilic loop, ER location, and they all have been proposed to regulate auxin homeostasis [30,75,77-79]. Interestingly, in the present study, both OePIN5a and OePIN6 showed a similar expression profile. In IBA-treated explants, both transcripts recover their basal expression levels before the end of the rooting trial (specifically, during the initiation phase), suggesting that the application of exogenous auxin might contribute to a retrieval of the basal expression levels observed at 0 hai, and therefore contribute to auxin homeostasis at this phase of the rooting process.

The present study also demonstrates that ROS levels were further reduced $8 \mathrm{~h}$ after inoculation in both nontreated and IBA-treated stems (Figure 2B,D,F,H), which might result from increased expression of the alternative oxidase (AOX) gene, as previously shown [80]. Consequently, this could lead to increased expression of the corresponding AOX protein, which has been reported to have a function in regulating ROS levels [81]. Given this function, AOX has been described to play a crucial role in redox regulation at a cellular level on environmental stresses [82]. Moreover, the production of ROS by mitochondria was suggested to be a critical factor for the induction of AOX [83-85]. Interestingly, Ivanova et al. [86] found a relationship between AOX and auxin efflux carriers. They showed that Arabidopsis PIN1, PIN3, PIN4, and PIN7 genes were significantly downregulated when $A O X 1 a$ was 
induced by antimycin A (an inhibitor of the mitochondrial electron transport chain). The authors suggested that $A O X 1 a$ induction represses auxin cell-to-cell transport and auxin signaling. It is worth noting that our previous study [80], found a dramatic upregulation of the OeAOX1a gene in both nontreated and IBA-treated microcuttings. Taken together, our previous [80] and current findings show an association between ROS accumulation and a dramatic downregulation of most olive PIN genes, as well as induced expression of olive AOX1 gene. This corroborates other previous studies $[48-51,86]$ which describe an interplay between stress-induced ROS and auxin signaling.

In summary, we show here that the stress situation (caused by wounding) associated with explant preparation for rooting, and the resultant increased production of ROS, could impact on auxin transport and distribution through alterations in the expression of OePIN genes. Moreover, the application of exogenous auxin, through regulation of those genes, may play a role modulating auxin homeostasis and leading to auxin redistribution throughout the stem-base tissues, which may play an important role in AR formation. Further studies are required to elucidate the precise biological functions of the PIN gene family during AR formation in olive, namely, tissue-specific localization of these genes in olive stem-base tissues, as well as development of transgenic lines (overexpressing for example OePIN5b), which may provide new insights on the molecular mechanisms underlying this developmental process.

\section{Materials and Methods}

\subsection{Plant Material and In Vitro Rooting Trials}

Olea europaea L. plantlets of cv. 'Galega vulgar' (clone 1441) have been maintained under in vitro conditions since 2005 [87] and were used as the initial explant source for AR trials. Treatments for rooting induction were performed according to others [37] with some modifications. Briefly, stem cuttings (microcuttings) with four to five nodes were prepared from the upper part of in vitro-cultured plantlets and all leaves were removed except for the upper four. The base (approx. $1.0 \mathrm{~cm}$ ) of each microcutting was immersed in a sterile solution of $14.7 \mathrm{mM}$ IBA for $10 \mathrm{~s}$ [46]. Immediately after, microcuttings were aseptically inoculated in $500 \mathrm{~mL}$ glass flasks containing $75 \mathrm{~mL}$ semi-solid olive culture medium $(\mathrm{OM})$, without plant growth regulators and supplemented with $7 \mathrm{~g} / \mathrm{L}$ commercial agar-agar, $30 \mathrm{~g} / \mathrm{L} \mathrm{d}$-mannitol, and $2 \mathrm{~g} / \mathrm{L}$ activated charcoal [88]. Medium $\mathrm{pH}$ was adjusted to 5.8 prior to autoclaving $\left(20 \mathrm{~min}\right.$ at $121^{\circ} \mathrm{C}, 1 \mathrm{~kg} / \mathrm{cm}^{2}$ ). Twenty microcuttings were inoculated per flask and four flasks were used per time point. Time points used here corresponded to time after inoculation in the culture medium and corresponded to $0,4,8,24$ (1 day), 96 (4 days), 192 (8 days), and 408 (17 days) $\mathrm{h}$. Time point $0 \mathrm{~h}$ refers to microcuttings that were immediately frozen and stored after preparation for rooting assay and, thus, were not inoculated in the culture medium. All cultures were kept in a plant growth chamber at $24^{\circ} \mathrm{C} / 21^{\circ} \mathrm{C}\left( \pm 1^{\circ} \mathrm{C}\right)$ day/night temperatures, with a $15 \mathrm{~h}$ photoperiod, under cool-white fluorescent light at a photosynthetically active radiation (PAR) level of $36 \mu \mathrm{mol} / \mathrm{m}^{2} \mathrm{~s}^{-2}$ at culture height. During in vitro rooting experiments, the segments from the basal portion (approx. $1 \mathrm{~cm}$ from the base) of the microcuttings were collected from each flask at the time points indicated above. Basal segments from control microcuttings, prepared as described above, but not immersed in IBA, were also collected at the same time points and those corresponded to the nontreated microcuttings. All samples were flash frozen in liquid nitrogen and stored at $-80^{\circ} \mathrm{C}$ for subsequent analyses.

\subsection{RNA Isolation and First-Strand cDNA Synthesis}

Total RNA was isolated with the Maxwell 16 LEV simplyRNA purification kit (Promega, Madison, WI, USA) on a Maxwell 16 Instrument (Promega, Madison, WI, USA) according to the supplier's instructions, and eluted in $50 \mu \mathrm{L}$ of RNase-free water. The concentration of total RNA was determined with a NanoDrop-2000C spectrophotometer (Thermo Scientific, Wilmington, DE, USA), and RNA integrity was evaluated by agarose gel electrophoresis through visualization of the two ribosomal subunits in a Gene Flash Bio Imaging system (Syngene, Cambridge, UK). The GoScript Reverse Transcription System (Promega, Madison, WI, USA) was used to synthesize complementary DNA (cDNA) from RNA samples (using $1 \mu \mathrm{g}$ of total RNA), according to manufacturer's instructions. 


\subsection{Quantitative Real-Time PCR ( $q P C R$ )}

Real-time PCR was performed with the Applied Biosystems 7500 Real-Time PCR System (Applied Biosystems, Foster City, CA, USA). Real-time PCR reactions were carried out using 1× Maxima SYBR Green qPCR Master Mix, 20 ng of cDNA, and specific primers (300 nM) for target and reference genes (Table 1), in a total volume of $18 \mu \mathrm{L}$. Specific primers were designed with Primer Express v3.0 (Applied Biosystems, Foster City, CA, USA) using default software settings, and were based on the putative OePIN members sequences obtained at the olive genome database (var. europaea, cv. Farga) (http://denovo.cnag.cat/genomes/olive/) using the Oe6 browser (Table 1). Phylogenetic analysis was performed using putative olive PIN sequences and 120 PIN proteins from 11 eudicot plant species (Hélia Cardoso, personal communication), according to others [89-92]. Actin (OeACT) and the elongation factor 1a $(O e E F 1 a)$ were used as reference genes for expression data normalization. All primer pairs were checked for their probability to form dimers and secondary structures using the primer test tool of the software. The reactions were performed using the following thermal profile: $10 \mathrm{~min}$ at $95^{\circ} \mathrm{C}$, and 40 cycles of $15 \mathrm{~s}$ at $95^{\circ} \mathrm{C}$ and $60 \mathrm{~s}$ at $60^{\circ} \mathrm{C}$. No-template controls (NTCs) were used to assess contaminations and primer dimers formation. A standard curve, with a total of four points, was performed using an undiluted pool containing all cDNA samples and three four-fold serial dilutions. All samples were analyzed in duplicate. Melting curve analysis was done to ensure amplification of the specific amplicon. Quantification cycle (Cq) values were acquired for each sample with the Applied Biosystems 7500 software (Applied Biosystems, Foster City, CA, USA).

Table 1. Primers used for RT-qPCR analysis designed based on PIN sequences retrieved from Olea euroapaea subsp. europaea var. europaea (cv. 'Farga').

\begin{tabular}{|c|c|c|c|}
\hline Gene & Locus ID & Primer Sequences $5^{\prime} \rightarrow 3^{\prime}$ & $\begin{array}{l}\text { Amplicon } \\
\text { Size (bp) }\end{array}$ \\
\hline OePIN1a & OE6A110180 & $\begin{array}{c}\text { Fw: TATGAGAAGGGCAGTAGAAGATTAGAGCAT } \\
\text { Rv: GGGCCAATGAATTCCGTTTC }\end{array}$ & 86 \\
\hline OePIN1b & OE6A100299 & $\begin{array}{l}\text { Fw: TGCTGGGATTATGAAAAGGAA } \\
\text { Rv: TTGGTGATCCCAACTTCAAA }\end{array}$ & 82 \\
\hline OePIN1c & OE6A008174 & $\begin{array}{l}\text { Fw: GGCTATGAATGTGATGTGTCGAT } \\
\text { Rv: TTTCGGTGTCCAAGTCTTTGA }\end{array}$ & 64 \\
\hline OePIN2b & OE6A029229 & $\begin{array}{c}\text { Fw: CTTCTTGGGGTGTAACTTTGG } \\
\text { Rv: AAAAACAAGCAACAAGAACATCA }\end{array}$ & 147 \\
\hline OePIN3a & OE6A013411 & $\begin{array}{l}\text { Fw: TTTGGAATGTTGATTGCATTG } \\
\text { Rv: TTCAACGAAGCGTCACAATC }\end{array}$ & 128 \\
\hline OePIN3b & OE6A121027 & $\begin{array}{c}\text { Fw: TCCCGATTACGCTCGTCTAT } \\
\text { Rv: TTTGACACCATTTTCACACAGTC }\end{array}$ & 84 \\
\hline OePIN3c & OE6A040519 & $\begin{array}{l}\text { Fw: ATCGCGCTACCGATTACACT } \\
\text { Rv: CCCGAATATGACCAAGAACAA }\end{array}$ & 72 \\
\hline OePIN5a & OE6A089248 & $\begin{array}{l}\text { Fw: CGTCATTTTAGATAGTATCCATTGATGT } \\
\text { Rv: TTTATACTGGAAAGTCCTAGTCAGCA }\end{array}$ & 53 \\
\hline OePIN5b & OE6A062743 & $\begin{array}{l}\text { Fw: GCTTCCACTCTTGATTGGCTA } \\
\text { Rv: TGGATCGTCAGATGCAAACT }\end{array}$ & 82 \\
\hline OePIN5c & OE6A015595 & $\begin{array}{l}\text { Fw: GGTGTTGATCGGATATTATGCAGTT } \\
\text { Rv: ATGATCCAAAATTTAGCCATGAAAAC }\end{array}$ & 125 \\
\hline OePIN6 & OE6A074435 & $\begin{array}{l}\text { Fw: CCCGTGACCCTTGTCTATTACATAT } \\
\text { Rv: TTATCCTTTTCCTTTTTGTTCCAACT }\end{array}$ & 72 \\
\hline OePIN8 & OE6A113148 & $\begin{array}{l}\text { Fw: GCCAATTGCATTAGCCTACTACTTC } \\
\text { Rv: GCACGAGATGAATCTTGTGTTATCA }\end{array}$ & 74 \\
\hline
\end{tabular}




\subsection{Transcript Expression Analysis}

For transcript expression levels normalization, $\mathrm{Cq}$ values were converted into relative quantities (RQ) by the delta-Ct method described by Vandesompele and co-authors [93]. The normalization factor was determined by the GeNorm algorithm [93], which corresponds to the geometric mean between the RQ of the selected reference genes for each sample. Finally, calculating the ratio between the RQ for each sample and the corresponding normalization factor, a normalized gene expression value was obtained for each gene of interest.

\subsection{Histochemical Detection of Reactive Oxygen Species (ROS)}

Twelve nontreated and IBA-treated microcuttings prior to inoculation (at $0 \mathrm{~h}$ ) and $8 \mathrm{~h}$ after inoculation were used for ROS detection. Hydrogen peroxide $\left(\mathrm{H}_{2} \mathrm{O}_{2}\right)$ was detected with 3,3'-diaminobenzidine (DAB) (Alfa Aesar, Karlsruhe, Germany), and superoxide anion $\left(\mathrm{O}_{2}^{\bullet-}\right.$ ) was detected with nitroblue tetrazolium (NBT) (Alfa Aesar, Karlsruhe, Germany). The detection of $\mathrm{H}_{2} \mathrm{O}_{2}$ and $\mathrm{O}_{2}{ }^{\bullet-}$ was performed as described by others [94-96] with some modifications. Briefly, for the detection of $\mathrm{H}_{2} \mathrm{O}_{2}$, microcuttings were immersed in $10 \mathrm{mM}$ disodium hydrogen phosphate buffer $\mathrm{pH}$ 7.5 containing $0.05 \%(v / v)$ Tween 20 and $0.1 \%$ DAB; and for the detection of $\mathrm{O}_{2}^{\bullet-}$, microcuttings were immersed in $50 \mathrm{mM}$ sodium phosphate buffer (prepared with sodium dihydrogen phosphate and disodium hydrogen phosphate) $\mathrm{pH} 7.5$ containing $0.2 \%$ NBT. Microcuttings were incubated in DAB and NBT staining solutions in $50 \mathrm{~mL}$ falcon tubes (covered with aluminum foil) overnight at room temperature. Following incubation, the staining solutions were replaced by a chlorophyll removal solution containing ethanol, acetic acid, and glycerol in a proportion of $(3: 1: 1, v / v)$ and microcuttings were then placed in a boiling water bath (at $95^{\circ} \mathrm{C}$ ) with intermittent shaking for 15 min to completely remove the chlorophyll from the tissues. The removal solution was replaced by a fresh one and microcuttings were allowed to stand for $30 \mathrm{~min}$ before photographs were taken. $\mathrm{H}_{2} \mathrm{O}_{2}$ was visualized as a dark brown precipitate and $\mathrm{O}_{2}{ }^{\bullet-}$ as a dark blue precipitate in the tissue. Microcuttings immersed in $10 \mathrm{mM}$ disodium phosphate buffer $\mathrm{pH} 7.5$ and in $50 \mathrm{mM}$ sodium phosphate buffer $\mathrm{pH}$ 7.5, without $\mathrm{DAB}$ and NBT, respectively, were used as controls.

\subsection{Statistical Analysis}

The graphs of relative mRNA expression levels show the mean ( $\log _{10}$ transformed $) \pm$ standard error of the mean (SEM) of four biological replicates (each consisting of a pool of 20 stem basal segments) for each time point and for each experimental condition (nontreated and IBA-treated). Statistical significances among different time points after inoculation were evaluated by one-way analysis of variance (ANOVA, $p<0.05$ ), followed by Tukey's honest significant difference (HSD) post-hoc test $(p<0.05)$, when normality (by Shapiro-Wilk test) and/or homogeneity of variances (by Bartlett's test) were verified. When the assumptions of one-way ANOVA test were not met, the Kruskal-Wallis test $(p<0.05)$ followed by the Pairwise Wilcoxon Rank Sum test (also called Mann-Whitney test) ( $p$ $<0.05)$ were used instead. Student's $t$-test $\left({ }^{*} p \leq 0.05,{ }^{* *} p \leq 0.01,{ }^{* * *} p \leq 0.001\right)$ was adopted when comparing between conditions (no treatment vs. treatment with IBA) within the same time point and when normality (by Shapiro-Wilk test) and/or homogeneity of variances (by Bartlett's test) were verified. Otherwise, the unpaired two-samples Wilcoxon test $\left({ }^{*} p \leq 0.05,{ }^{* *} p \leq 0.01,{ }^{* * *} p \leq 0.001\right)$ was applied. Distinct letters indicate statistically significant differences $(p<0.05)$ within the same condition. All statistical analyses were performed using the computing environment $R$ [97].

Author Contributions: conceptualization, I.V., H.C. and A.P.; methodology, I.V.; formal analysis, I.V. and H.C.; investigation, I.V.; resources, A.P.; writing—original draft preparation, I.V.; writing—review and editing, I.V., S.P. and A.P.; funding acquisition, A.P. All authors have read and agreed to the published version of the manuscript. 
Funding: This research was funded by National Funds through FCT-Foundation for Science and Technology under the Project UIDB/05183/2020 and by FEDER and National Funds through the ALENTEJO 2020 (Regional Operational Program of the Alentejo), Operação ALT20-03-0145-FEDER-000014-“"Valorização das Variedades de Oliveira Portuguesas (OLEAVALOR)". The HC was funded by the FCT post-doc fellowship SFRH/BPD/109849/2015 and the IV was supported by the post-doc1_oleavalor fellowship within the Project OLEAVALOR (ALT20-03-0145-FEDER-000014).

Acknowledgments: The authors are grateful to Virgínia Sobral (Plant Breeding and Biotechnology Lab, University of Évora) for technical support with rooting assays and to Catarina Meireles (MED, University of Évora) for her critical help with statistical analysis in R environment.

Conflicts of Interest: The authors declare no conflict of interest. The funders had no role in the design of the study; in the collection, analyses, or interpretation of data; in the writing of the manuscript, or in the decision to publish the results.

\section{References}

1. Tanaka, H.; Dhonukshe, P.; Brewer, P.B.; Friml, J. Spatiotemporal asymmetric auxin distribution: A means to coordinate plant development. Cell. Mol. Life Sci. C 2006, 63, 2738-2754. [CrossRef]

2. Teale, W.D.; Paponov, I.A.; Palme, K. Auxin in action: Signalling, transport and the control of plant growth and development. Nat. Rev. Mol. Cell Biol. 2006, 7, 847-859. [CrossRef] [PubMed]

3. Vanneste, S.; Friml, J. Auxin: A Trigger for Change in Plant Development. Cell 2009, 136, $1005-1016$. [CrossRef] [PubMed]

4. Wolters, H.; Anders, N.; Geldner, N.; Gavidia, R.; Jurgens, G. Coordination of apical and basal embryo development revealed by tissue-specific GNOM functions. Development 2010, 138, 117-126. [CrossRef] [PubMed]

5. Swarup, R.; Kramer, E.M.; Perry, P.; Knox, K.; Leyser, H.M.O.; Haseloff, J.; Beemster, G.T.S.; Bhalerao, R.; Bennett, M.J. Root gravitropism requires lateral root cap and epidermal cells for transport and response to a mobile auxin signal. Nat. Cell Biol. 2005, 7, 1057-1065. [CrossRef]

6. Swarup, K.; Benková, E.; Swarup, R.; Casimiro, I.; Péret, B.; Yang, Y.; Parry, G.; Nielsen, E.; De Smet, I.; Vanneste, S.; et al. The auxin influx carrier LAX3 promotes lateral root emergence. Nat. Cell Biol. 2008, 10, 946-954. [CrossRef]

7. Overvoorde, P.; Fukaki, H.; Beeckman, T. Auxin control of root development. Cold Spring Harb. Perspect. Biol. 2010, 2, a001537. [CrossRef]

8. Lewis, D.R.; Negi, S.; Sukumar, P.; Muday, G.K. Ethylene inhibits lateral root development, increases IAA transport and expression of PIN3 and PIN7 auxin efflux carriers. Development 2011, 138, 3485-3495. [CrossRef]

9. Dubrovsky, J.G.; Sauer, M.; Napsucialy-Mendivil, S.; Ivanchenko, M.G.; Friml, J.; Shishkova, S.; Celenza, J.; Benková, E. Auxin acts as a local morphogenetic trigger to specify lateral root founder cells. Proc. Natl. Acad. Sci. USA 2008, 105, 8790-8794. [CrossRef]

10. Blakeslee, J.J. Relocalization of the PIN1 Auxin Efflux Facilitator Plays a Role in Phototropic Responses. Plant Physiol. 2004, 134, 28-31. [CrossRef]

11. Kimura, M.; Kagawa, T. Phototropin and light-signaling in phototropism. Curr. Opin. Plant Biol. 2006, 9, 503-508. [CrossRef]

12. Palme, K.; Dovzhenko, A.; Ditengou, F.A. Auxin transport and gravitational research: Perspectives. Protoplasma 2006, 229, 175-181. [CrossRef]

13. Zahir, Z.A.; Shah, M.K.; Naveed, M.; Akhter, M.J. Substrate-dependent auxin production by Rhizobium phaseoli improves the growth and yield of Vigna radiata L. under salt stress conditions. J. Microbiol. Biotechnol. 2010, 20, 1288-1294. [CrossRef]

14. Van Ha, C.; Le, D.T.; Nishiyama, R.; Watanabe, Y.; Sulieman, S.; Tran, U.T.; Mochida, K.; Van Dong, N.; Yamaguchi-Shinozaki, K.; Shinozaki, K.; et al. The auxin response factor transcription factor family in soybean: Genome-wide identification and expression analyses during development and water stress. DNA Res. 2013, 20, 511-524. [CrossRef]

15. Min, L.; Li, Y.; Hu, Q.; Zhu, L.; Gao, W.; Wu, Y.; Ding, Y.; Liu, S.; Yang, X.; Zhang, X. Sugar and Auxin Signaling Pathways Respond to High-Temperature Stress during Anther Development as Revealed by Transcript Profiling Analysis in Cotton. Plant Physiol. 2014, 164, 1293-1308. [CrossRef] 
16. Prusinkiewicz, P.; Crawford, S.; Smith, R.S.; Ljung, K.; Bennett, T.; Ongaro, V.; Leyser, O. Control of bud activation by an auxin transport switch. Proc. Natl. Acad. Sci. USA 2009, 106, 17431-17436. [CrossRef]

17. Leyser, O. The fall and rise of apical dominance. Curr. Opin. Genet. Dev. 2005, 15, 468-471. [CrossRef]

18. Bainbridge, K.; Guyomarc'h, S.; Bayer, E.; Swarup, R.; Bennett, M.; Mandel, T.; Kuhlemeier, C. Auxin influx carriers stabilize phyllotactic patterning. Genes Dev. 2008, 22, 810-823. [CrossRef]

19. Guenot, B.; Bayer, E.; Kierzkowski, D.; Smith, R.S.; Mandel, T.; Zadnikova, P.; Benkova, E.; Kuhlemeier, C. PIN1-Independent Leaf Initiation in Arabidopsis. Plant Physiol. 2012, 159, 1501-1510. [CrossRef]

20. van Noorden, G.E.; Kerim, T.; Goffard, N.; Wiblin, R.; Pellerone, F.I.; Rolfe, B.G.; Mathesius, U. Overlap of Proteome Changes in Medicago truncatula in Response to Auxin and Sinorhizobium meliloti. Plant Physiol. 2007, 144, 1115-1131. [CrossRef]

21. Reinhardt, D.; Mandel, T.; Kuhlemeier, C. Auxin Regulates the Initiation and Radial Position of Plant Lateral Organs. Plant Cell 2007, 12, 507. [CrossRef] [PubMed]

22. Reinhardt, D.; Pesce, E.-R.; Stieger, P.; Mandel, T.; Baltensperger, K.; Bennett, M.; Traas, J.; Friml, J.; Kuhlemeier, C. Regulation of phyllotaxis by polar auxin transport. Nature 2003, 426, 255-260. [CrossRef] [PubMed]

23. Heisler, M.G.; Ohno, C.; Das, P.; Sieber, P.; Reddy, G.V.; Long, J.A.; Meyerowitz, E.M. Patterns of auxin transport and gene expression during primordium development revealed by live imaging of the Arabidopsis inflorescence meristem. Curr. Biol. 2005, 15, 1899-1911. [CrossRef] [PubMed]

24. Woodward, A.W.; Bartel, B. Auxin: Regulation, action, and interaction. Ann. Bot. 2005, 95, 707-735. [CrossRef]

25. Zhao, Y. Auxin Biosynthesis and Its Role in Plant Development. Annu. Rev. Plant Biol. 2010, 61, 49-64. [CrossRef]

26. Zažímalová, E.; Křeček, P.; Skůpa, P.; Hoyerová, K.; Petrášek, J. Polar transport of the plant hormone auxin-The role of PIN-FORMED (PIN) proteins. Cell. Mol. Life Sci. 2007, 64, 1621-1637. [CrossRef]

27. Petrasek, J.; Friml, J. Auxin transport routes in plant development. Development 2009, 136, $2675-2688$. [CrossRef]

28. Robert, H.S.; Friml, J. Auxin and other signals on the move in plants. Nat. Chem. Biol. 2009, 5, 325-332. [CrossRef] [PubMed]

29. Wabnik, K.; Kleine-Vehn, J.; Govaerts, W.; Friml, J. Prototype cell-to-cell auxin transport mechanism by intracellular auxin compartmentalization. Trends Plant Sci. 2011, 16, 468-475. [CrossRef]

30. Křeček, P.; Skůpa, P.; Libus, J.; Naramoto, S.; Tejos, R.; Friml, J.; Zažímalová, E. The PIN-FORMED (PIN) protein family of auxin transporters. Genome Biol. 2009, 10, 249. [CrossRef]

31. Xu, M.; Zhu, L.; Shou, H.; Wu, P. A PIN1 family gene, OsPIN1, involved in auxin-dependent adventitious root emergence and tillering in rice. Plant Cell Physiol. 2005, 46, 1674-1681. [CrossRef] [PubMed]

32. Zhou, J.-J.; Luo, J. The PIN-FORMED Auxin Efflux Carriers in Plants. Int. J. Mol. Sci. 2018, 19, 2759. [CrossRef] [PubMed]

33. Steffens, B.; Rasmussen, A. The Physiology of Adventitious Roots. Plant Physiol. 2016, 170, $603-617$. [CrossRef] [PubMed]

34. Porfirio, S.; Calado, M.L.; Noceda, C.; Cabrita, M.J.; da Silva, M.G.; Azadi, P.; Peixe, A. Tracking biochemical changes during adventitious root formation in olive (Olea europaea L.). Sci. Hortic. 2016, 204, 41-53. [CrossRef]

35. Guan, L.; Murphy, A.S.; Peer, W.A.; Gan, L.; Li, Y.; Cheng, Z.M. (Max) Physiological and Molecular Regulation of Adventitious Root Formation. CRC Crit. Rev. Plant Sci. 2015, 34, 506-521. [CrossRef]

36. Porfírio, S.; Gomes da Silva, M.D.R.; Cabrita, M.J.; Azadi, P.; Peixe, A. Reviewing current knowledge on olive (Olea europaea L.) adventitious root formation. Sci. Hortic. 2016, 198, 207-226. [CrossRef]

37. Macedo, E.; Vieira, C.; Carrizo, D.; Porfírio, S.; Hegewald, H.; Arnholdt-Schmitt, B.; Calado, M.L.; Peixe, A. Adventitious root formation in olive (Olea europaea L.) microshoots: Anatomical evaluation and associated biochemical changes in peroxidase and polyphenoloxidase activities. J. Hortic. Sci. Biotechnol. 2013. [CrossRef]

38. Pacurar, D.I.; Perrone, I.; Bellini, C. Auxin is a central player in the hormone cross-talks that control adventitious rooting. Physiol. Plant. 2014, 151, 83-96. [CrossRef]

39. Pop, T.I.; Pamfil, D.; Bellini, C. Auxin control in the formation of adventitious roots. Not. Bot. Horti Agrobot. Cluj-Napoca 2011, 39, 307-316. [CrossRef] 
40. Vidoz, M.L.; Loreti, E.; Mensuali, A.; Alpi, A.; Perata, P. Hormonal interplay during adventitious root formation in flooded tomato plants. Plant J. 2010, 63, 551-562. [CrossRef]

41. Ford, Y.Y.; Bonham, E.C.; Cameron, R.W.F.; Blake, P.S.; Judd, H.L.; Harrison-Murray, R.S. Adventitious rooting: Examining the role of auxin in an easy- and a difficult-to-root plant. Plant Growth Regul. 2002, 36, 149-159. [CrossRef]

42. Liu, S.; Wang, J.; Wang, L.; Wang, X.; Xue, Y.; Wu, P.; Shou, H. Adventitious root formation in rice requires OsGNOM1 and is mediated by the OsPINs family. Cell Res. 2009, 19, 1110-1119. [CrossRef] [PubMed]

43. Brinker, M. Microarray Analyses of Gene Expression during Adventitious Root Development in Pinus contorta. Plant Physiol. 2004, 135, 1526-1539. [CrossRef] [PubMed]

44. Arnholdt-Schmitt, B.; Costa, J.H.; de Melo, D.F. AOX-A functional marker for efficient cell reprogramming under stress? Trends Plant Sci. 2006, 11, 281-287. [CrossRef]

45. Arnholdt-Schmitt, B.; Santos Macedo, E.; Peixe, A.; Cardoso, H.; Cordeiro, A. AOX-A potential functional marker for efficient rooting in olive shoot cuttings. In Proceedings of the Second International Seminar Olivebioteq, Marsala Mazara del Vallo, Italy, 5-10 November 2006; pp. 249-254.

46. Santos Macedo, E.; Sircar, D.; Cardoso, H.G.; Peixe, A.; Arnholdt-Schmitt, B. Involvement of alternative oxidase (AOX) in adventitious rooting of Olea europaea L. microshoots is linked to adaptive phenylpropanoid and lignin metabolism. Plant Cell Rep. 2012, 31, 1581-1590. [CrossRef]

47. Apel, K.; Hirt, H. Reactive oxygen species: Metabolism, oxidative stress, and signal transduction. Annu. Rev. Plant Biol. 2004, 55, 373-399. [CrossRef]

48. Tognetti, V.B.; Mühlenbock, P.; van Breusegem, F. Stress homeostasis - the redox and auxin perspective. Plant Cell Environ. 2012, 35, 321-333. [CrossRef]

49. Potters, G.; Pasternak, T.P.; Guisez, Y.; Palme, K.J.; Jansen, M.A.K. Stress-induced morphogenic responses: Growing out of trouble? Trends Plant Sci. 2007, 12, 98-105. [CrossRef]

50. Potters, G.; Pasternak, T.P.; Guisez, Y.; Jansen, M.A.K. Different stresses, similar morphogenic responses: Integrating a plethora of pathways. Plant Cell Environ. 2009, 32, 158-169. [CrossRef]

51. Pasternak, T.; Potters, G.; Caubergs, R.; Jansen, M.A.K. Complementary interactions between oxidative stress and auxins control plant growth responses at plant, organ, and cellular level. J. Exp. Bot. 2005, 56, 1991-2001. [CrossRef]

52. Kovtun, Y.; Chiu, W.-L.; Tena, G.; Sheen, J. Functional analysis of oxidative stress-activated mitogen-activated protein kinase cascade in plants. Proc. Natl. Acad. Sci. USA 2002, 97, 2940-2945. [CrossRef] [PubMed]

53. Blomster, T.; Salojarvi, J.; Sipari, N.; Brosche, M.; Ahlfors, R.; Keinanen, M.; Overmyer, K.; Kangasjarvi, J. Apoplastic Reactive Oxygen Species Transiently Decrease Auxin Signaling and Cause Stress-Induced Morphogenic Response in Arabidopsis. Plant Physiol. 2011, 157, 1866-1883. [CrossRef] [PubMed]

54. Nakagami, H.; Soukupová, H.; Schikora, A.; Žárský, V.; Hirt, H. A mitogen-activated protein kinase kinase kinase mediates reactive oxygen species homeostasis in Arabidopsis. J. Biol. Chem. 2006, 281, 38697-38704. [CrossRef] [PubMed]

55. Xia, X.J.; Zhou, Y.H.; Shi, K.; Zhou, J.; Foyer, C.H.; Yu, J.Q. Interplay between reactive oxygen species and hormones in the control of plant development and stress tolerance. J. Exp. Bot. 2015, 66, 2839-2856. [CrossRef]

56. Peer, W.A.; Cheng, Y.; Murphy, A.S. Evidence of oxidative attenuation of auxin signalling. J. Exp. Bot. 2013, 64, 2629-2639. [CrossRef]

57. Choudhury, F.K.; Rivero, R.M.; Blumwald, E.; Mittler, R. Reactive oxygen species, abiotic stress and stress combination. Plant J. 2017, 90, 856-867. [CrossRef]

58. He, J.; Duan, Y.; Hua, D.; Fan, G.; Wang, L.; Liu, Y.; Chen, Z.; Han, L.; Qu, L.-J.; Gong, Z. DEXH Box RNA Helicase-Mediated Mitochondrial Reactive Oxygen Species Production in Arabidopsis Mediates Crosstalk between Abscisic Acid and Auxin Signaling. Plant Cell 2012, 24, 1815-1833. [CrossRef]

59. Kawano, T. Roles of the reactive oxygen species-generating peroxidase reactions in plant defense and growth induction. Plant Cell Rep. 2003, 21, 829-837. [CrossRef]

60. Grunewald, W.; Friml, J. The march of the PINs: Developmental plasticity by dynamic polar targeting in plant cells. EMBO J. 2010, 29, 2700-2714. [CrossRef]

61. Shen, C.J.; Bai, Y.H.; Wang, S.K.; Zhang, S.N.; Wu, Y.R.; Chen, M.; Jiang, D.A.; Qi, Y.H. Expression profile of PIN, AUX/LAX and PGP auxin transporter gene families in Sorghum bicolor under phytohormone and abiotic stress. FEBS J. 2010, 277, 2954-2969. [CrossRef] 
62. Shibasaki, K.; Uemura, M.; Tsurumi, S.; Rahman, A. Auxin Response in Arabidopsis under Cold Stress: Underlying Molecular Mechanisms. Plant Cell 2009, 21, 3823-3838. [CrossRef] [PubMed]

63. Santos MacEdo, E.; Cardoso, H.G.; Hernández, A.; Peixe, A.A.; Polidoros, A.; Ferreira, A.; Cordeiro, A.; Arnholdt-Schmitt, B. Physiologic responses and gene diversity indicate olive alternative oxidase as a potential source for markers involved in efficient adventitious root induction. Physiol. Plant. 2009, 137, 532-552. [CrossRef] [PubMed]

64. Fattorini, L.; Veloccia, A.; Della Rovere, F.; D’Angeli, S.; Falasca, G.; Altamura, M.M. Indole-3-butyric acid promotes adventitious rooting in Arabidopsis thaliana thin cell layers by conversion into indole-3-acetic acid and stimulation of anthranilate synthase activity. BMC Plant Biol. 2017, 17, 121. [CrossRef] [PubMed]

65. Estrella-Maldonado, H.; Fuentes Ortíz, G.; Chan León, A.C.; Rodríguez Zapata, L.C.; Talavera May, C.; Espadas y Gil, F.; Barredo Pool, F.; Idrovo Espín, F.M.; Santamaría, J.M. The papaya CpAUX1/LAX and CpPIN genes: Structure, phylogeny and expression analysis related to root formation on in vitro plantlets. Plant Cell. Tissue Organ Cult. 2016, 126, 187-204. [CrossRef]

66. Yue, R.; Tie, S.; Sun, T.; Zhang, L.; Yang, Y.; Qi, J.; Yan, S.; Han, X.; Wang, H.; Shen, C. Genome-wide identification and expression profiling analysis of ZmPIN, ZmPILS, ZmLAX and ZmABCB auxin transporter gene families in maize (Zea mays L.) under various abiotic stresses. PLoS ONE 2015, 10, e0118751. [CrossRef]

67. Wang, J.R.; Hu, H.; Wang, G.H.; Li, J.; Chen, J.Y.; Wu, P. Expression of PIN genes in rice (Oryza sativa L.): Tissue specificity and regulation by hormones. Mol. Plant 2009, 2, 823-831. [CrossRef]

68. Zazímalová, E.; Murphy, A.S.; Yang, H.; Hoyerová, K.; Hosek, P. Auxin transporters-Why so many? Cold Spring Harb. Perspect. Biol. 2010, 2, a001552. [CrossRef]

69. Della Rovere, F.; Fattorini, L.; Ronzan, M.; Falasca, G.; Altamura, M.M. The quiescent center and the stem cell niche in the adventitious roots of Arabidopsis thaliana. Plant Signal. Behav. 2016, 11, e1176660. [CrossRef]

70. Sukumar, P.; Maloney, G.S.; Muday, G.K. Localized Induction of the ATP-Binding Cassette B19 Auxin Transporter Enhances Adventitious Root Formation in Arabidopsis. Plant Physiol. 2013, 162, 1392-1405. [CrossRef]

71. Xu, W.; Jia, L.; ŠekBaluška, F.; Ding, G.; Shi, W.; Ye, N.; Zhang, J. PIN2 is required for the adaptation of Arabidopsis roots to alkaline stress by modulating proton secretion. J. Exp. Bot. 2012, 63, 6105-6114. [CrossRef]

72. Zhang, Q.; Li, J.; Zhang, W.; Yan, S.; Wang, R.; Zhao, J.; Li, Y.; Qi, Z.; Sun, Z.; Zhu, Z. The putative auxin efflux carrier OsPIN3t is involved in the drought stress response and drought tolerance. Plant J. 2012, 72, 805-816. [CrossRef] [PubMed]

73. Baluška, F.; Mancuso, S.; Volkmann, D.; Barlow, P.W. Root apex transition zone: A signalling-response nexus in the root. Trends Plant Sci. 2010, 15, 402-408. [CrossRef] [PubMed]

74. Du, H.; Liu, H.; Xiong, L. Endogenous auxin and jasmonic acid levels are differentially modulated by abiotic stresses in rice. Front. Plant Sci. 2013, 4, 397. [CrossRef] [PubMed]

75. Mravec, J.; Skůpa, P.; Bailly, A.; Hoyerová, K.; Křeček, P.; Bielach, A.; Petrášek, J.; Zhang, J.; Gaykova, V.; Stierhof, Y.D.; et al. Subcellular homeostasis of phytohormone auxin is mediated by the ER-localized PIN5 transporter. Nature 2009, 459, 1136-1140. [CrossRef]

76. Lu, G.; Coneva, V.; Casaretto, J.A.; Ying, S.; Mahmood, K.; Liu, F.; Nambara, E.; Bi, Y.M.; Rothstein, S.J. OsPIN5b modulates rice (Oryza sativa) plant architecture and yield by changing auxin homeostasis, transport and distribution. Plant J. 2015, 83, 913-925. [CrossRef]

77. Cazzonelli, C.I.; Vanstraelen, M.; Simon, S.; Yin, K.; Carron-Arthur, A.; Nisar, N.; Tarle, G.; Cuttriss, A.J.; Searle, I.R.; Benkova, E.; et al. Role of the Arabidopsis PIN6 Auxin Transporter in Auxin Homeostasis and Auxin-Mediated Development. PLoS ONE 2013, 8, e70069. [CrossRef]

78. Simon, S.; Skůpa, P.; Viaene, T.; Zwiewka, M.; Tejos, R.; Klíma, P.; Čarná, M.; Rolčík, J.; De Rycke, R.; Moreno, I.; et al. PIN6 auxin transporter at endoplasmic reticulum and plasma membrane mediates auxin homeostasis and organogenesis in Arabidopsis. New Phytol. 2016, 211, 65-74. [CrossRef] [PubMed]

79. Ding, Z.; Wang, B.; Moreno, I.; Duplá Ková, N.; Simon, S.; Carraro, N.; Reemmer, J.; Pě Nčí K, A.; Chen, X.; Tejos, R.; et al. ER-localized auxin transporter PIN8 regulates auxin homeostasis and male gametophyte development in Arabidopsis. Nat. Commun. 2012, 3, 1-11. [CrossRef]

80. Velada, I.; Grzebelus, D.; Lousa, D.; Soares, C.M.; Macedo, E.S.; Peixe, A.; Arnholdt-Schmitt, B.; Cardoso, H.G. AOX1-subfamily gene members in olea europaea cv. "Galega vulgar"-Gene characterization and expression of transcripts during IBA-induced in vitro adventitious rooting. Int. J. Mol. Sci. 2018, 19, 597. [CrossRef] 
81. Millar, A.H.; Whelan, J.; Soole, K.L.; Day, D.A. Organization and Regulation of Mitochondrial Respiration in Plants. Annu. Rev. Plant Biol. 2011, 62, 79-104. [CrossRef]

82. Vanlerberghe, G.C. Alternative oxidase: A mitochondrial respiratory pathway to maintain metabolic and signaling homeostasis during abiotic and biotic stress in plants. Int. J. Mol. Sci. 2013, 14, 6805-6847. [CrossRef] [PubMed]

83. Clifton, R.; Lister, R.; Parker, K.L.; Sappl, P.G.; Elhafez, D.; Millar, A.H.; Day, D.A.; Whelan, J. Stress-induced co-expression of alternative respiratory chain components in Arabidopsis thaliana. Plant Mol. Biol. 2005, 58, 193-212. [CrossRef] [PubMed]

84. Clifton, R.; Millar, A.H.; Whelan, J. Alternative oxidases in Arabidopsis: A comparative analysis of differential expression in the gene family provides new insights into function of non-phosphorylating bypasses. Biochim. Biophys. Acta Bioenerg. 2006, 1757, 730-741. [CrossRef] [PubMed]

85. Rhoads, D.M.; Umbach, A.L.; Subbaiah, C.C.; Siedow, J.N. Mitochondrial reactive oxygen species. Contribution to oxidative stress and interorganellar signaling. Plant Physiol. 2006, 141, 357-366. [CrossRef] [PubMed]

86. Ivanova, A.; Law, S.R.; Narsai, R.; Duncan, O.; Lee, J.-H.; Zhang, B.; Van Aken, O.; Radomiljac, J.D.; van der Merwe, M.; Yi, K.; et al. A Functional Antagonistic Relationship between Auxin and Mitochondrial Retrograde Signaling Regulates Alternative Oxidase1a Expression in Arabidopsis. Plant Physiol. 2014, 165, 1233-1254. [CrossRef]

87. Peixe, A.; Raposo, A.; Lourenço, R.; Cardoso, H.; Macedo, E. Coconut water and BAP successfully replaced zeatin in olive (Olea europaea L.) micropropagation. Sci. Hortic. 2007, 113, 1-7. [CrossRef]

88. Rugini, E. In vitro propagation of some olive (Olea europaea sativa L.) cultivars with different root-ability, and medium development using analytical data from developing shoots and embryos. Sci. Hortic. 1984, 24, 123-134. [CrossRef]

89. He, P.; Zhao, P.; Wang, L.; Zhang, Y.; Wang, X.; Xiao, H.; Yu, J.; Xiao, G. The PIN gene family in cotton (Gossypium hirsutum): Genome-wide identification and gene expression analyses during root development and abiotic stress responses. BMC Genom. 2017, 18, 1-10. [CrossRef]

90. Yang, C.; Wang, D.; Zhang, C.; Kong, N.; Ma, H.; Chen, Q. Comparative analysis of the PIN auxin transporter gene family in different plant species: A focus on structural and expression profiling of PINs in Solanum tuberosum. Int. J. Mol. Sci. 2019, 20, 3270. [CrossRef]

91. Sánchez-García, A.B.; Ibáñez, S.; Cano, A.; Acosta, M.; Pérez-Pérez, J.M. A comprehensive phylogeny of auxin homeostasis genes involved in adventitious root formation in carnation stem cuttings. PLoS ONE 2018, 13, e0196663. [CrossRef]

92. Yu, C.; Dong, W.; Zhan, Y.; Huang, Z.A.; Li, Z.; Kim, I.S.; Zhang, C. Genome-wide identification and expression analysis of CILAX, CIPIN and CIABCB genes families in Citrullus lanatus under various abiotic stresses and grafting. BMC Genet. 2017, 18, 1-15. [CrossRef] [PubMed]

93. Vandesompele, J.; De Preter, K.; Pattyn, F.; Poppe, B.; Van Roy, N.; De Paepe, A.; Speleman, F. Accurate normalization of real-time quantitative RT-PCR data by geometric averaging of multiple internal control genes. Genome Biol. 2002, 3, RESEARCH0034. [CrossRef] [PubMed]

94. Thordal-Christensen, H.; Zhang, Z.; Wei, Y.; Collinge, D.B. Subcellular localization of H2O2 in plants. H2O2 accumulation in papillae and hypersensitive response during the barley-powdery mildew interaction. Plant J. 1997, 11, 1187-1194. [CrossRef]

95. Daudi, A.; O'Brien, J. Detection of Hydrogen Peroxide by DAB Staining in Arabidopsis Leaves. BIO-PROTOCOL 2012, 2, 1-4. [CrossRef]

96. Kumar, D.; Yusuf, M.; Singh, P.; Sardar, M.; Sarin, N. Histochemical Detection of Superoxide and H2O2 Accumulation in Brassica juncea Seedlings. Bio-Protocol 2014, 4, e1108. [CrossRef]

97. R Development Core Team. R: A Language and Environment for Statistical Computing; R Foundation for Statistical Computing: Vienna, Austria, 2018.

(C) 2020 by the authors. Licensee MDPI, Basel, Switzerland. This article is an open access article distributed under the terms and conditions of the Creative Commons Attribution (CC BY) license (http://creativecommons.org/licenses/by/4.0/). 